\title{
Revisiting the Tenets of Critical Pedagogy in Postmethod Pedagogy to Highlight the Concept of Intellectualism
}

Siavash Zokaeieh*, Ebrahim Fakhri Alamdari

Department of English Language and Literature, University of Qaemshahr 61964 47651, Mazandaran, Iran

Corresponding Author: Siavash Zokaeieh, E-mail: szokaieh@gmail.com

\section{ARTICLE INFO}

Article history

Received: November 04, 2017

Accepted: January 14, 2018

Published: May 01, 2018

Volume: 7 Issue: 3

Advance access: March 2018

Conflicts of interest: None

Funding: None

\begin{abstract}
Postmethod pedagogy and critical pedagogy have influential roles in education and language teaching. A number of practitioners may claim to instruct based on the tenets of postmethod pedagogy, however, they may not be entirely aware of the oppositional intention and dynamicity of this model. This article aims at revisiting the tenets and constructing elements of critical pedagogy and Freire's point of view vis-a-vis postmethod pedagogy and Kumaravadivelu's developed model to enlighten the open-mindedness and dynamic perceptions of these interwoven approaches. Furthermore, some criticisms towards critical pedagogy and postmethod pedagogy are brought into consideration for better understanding of the relevance and the weaknesses. It is hoped that by bringing these two notions, teachers especially those who wish to use postmethod pedagogy in their setting become more aware of the intellectual priorities of critical pedagogy and postmethod pedagogy such as moving from banking model of education, absence of bias and deviation from predetermined and fixed frameworks in the classrooms.
\end{abstract}

Key words: Critical Pedagogy, Postmethod Pedagogy, Intellectualism, Tenets, Criticism

\section{INTRODUCTION}

One of the main endeavors in critical language studies is done by Paulo Freire (1970) who is well-known for his critical pedagogy (CP). This model gave a direction in labyrinth of theories in critical language studies. According to the practitioners of this field, the legacy of critical pedagogy elucidates the power relations in social, economic, political agenda along with notions such as inequality in races and genders. However, this concept not only investigates the aforementioned elements, but also scrutinizes in depth and breathes of every aspect related to language teaching and learning. CP is defined by Shor (1992) as:

habits of thought, reading, writing, and speaking which go beneath surface meaning, first impressions, dominant myths, official pronouncement, traditional clichés, revised wisdom, and mere opinions, to understand the deep meaning, root cause, social context, ideology, and personal consequences of any action, event, object, process, organization, experience, texts, subject matter, mass media, or discourse. (p. 97)

The reason for the adoption of this definition is to show that CP goes beyond the melancholic assumptions of EFL/ ESL practitioners where only limited number of criteria are subjugated in their hearts and minds. This definition highlights durable notion of $\mathrm{CP}$ in various circumstances. To illustrate, Chege (2009) investigated political aspects of literacy by taking CP into account. Similarly, Kincheloe (2008) considered education as a political enterprise. Leonardo (2002) studied the aspect of race and skin color via strands of CP. These studies were mentioned to support the claim that only limited perception far from direct classroom implementation was at focal attention. In addition, CP is not restricted to the repeated theoretical assumptions at macro levels and the applicability of this notion to micro levels or classroom experimentation might be magnificent.

By considering the CP definition as articulated by Shor, who is one of the prominent researchers in $\mathrm{CP}$, one can realize two important concepts of surface meaning and deep meaning in this definition. Taking the mentioned variables into account, we can see that the tenets of $\mathrm{CP}$ are directly applicable to more empirical studies. Barjeste, Alipour and Vaseghi (2013) investigated the effect of CP strategies on reading comprehension of Iranian EFL learners. Participants of this study were junior sophomores majored in English translation. The main instruments for measuring their comprehension and critical thinking were test of comprehension along with the Waston-Glase's (2002) critical thinking appraisal-form. Their result indicated that $\mathrm{CP}$ strategies had a significant effect on reading comprehension of the participants. On the other hand, the multi-laired and multi-dimension characteristics of CP might enhance the field (Fischman and McLaren, 2005). They believed that CP was the most controversial school of thought after its first proposal. According to the definition and the review of the articles we can 
realize that this field considers the macro-level theoretical concepts and the micro-level pedagogical precepts.

Another newly developed revolutionary approach to education is the postmethod pedagogy (henceforth PP). PP is "based on a different way of looking at problems and prospects of language teaching" (Kumaravadivelu, 2006, p. 215). The concept of PP is not a single theoretical assumption, but a guide line at macro levels for teachers and practitioners to abolish the method fetishism. This notion is quite new in the realm of language related studies. Huda (2013) stated that the term postmethod was first coined by Pennycoock (1989), but Kumaravadivelu is the one who developed this notion globally. In other words, number of scholars remarked on this notion such as Rivers (1968) who worked on the concept of eclecticism, or Richards (1990) who noted the idea of the beyond method, but Kumaravadivelu (1994) was the one who academically defined and characterized it. It is also of value to distinguish the concept of eclecticism from PP. Kumaravadivelu (2006) mentioned that eclectic method was method based model of instruction. Additionally, Stern (1983) believed that "eclecticism is still based on the conceptual distinctiveness of different methods. However, it is the distinctiveness of the methods as complete entities that can be called into question" (p. 482). This common belief was accentuated by the discussion of Widdowson (1990) about randomness and expedient action in the eclectic approach (cited in Kumaravadivelu, 2006). In essence, teachers' characteristics are different in eclectic approach and PP.

PP has its roots in poststructuralism, postmodernism, postcolonialism, and it is derived from the philosophers and masterminds such as Foucalt (Kumaravadivelu, 2006). The effects of the mentioned ideologies and disciplines on language teaching theories and practices can be delved in postmethod pedagogy (Ahmadian \& Erfanrad, 2014). By this single clue one can feel the oppositional aims and objectives of postmethod. Furthermore, the strands of critical language studies in postmethod approach might become clear. Postmethod pedagogy needs open minded practitioners with involved intellectual level to obtain the signified concepts such as alternative to method, teachers' autonomy and principled pragmatism in accordance to local needs, wants and constraints (Kumaravadivelu, 1994; Hashemi, 2011). This might be one of the reasons why Kumaravadivelu (2006) emphasized on changing attitudes and beliefs along with the creation of an atmosphere to sustain postmethod pedagogy. To elaborate, some practitioners believe that postmethod put an end to the concept of method; in contrast, Kumaravadivelu (1994) clearly stated that postmethod is not a methodless notion rather "it means that the framework is not conditioned by a single set of theoretical principles or classroom procedures associated with any one particular language teaching methods" (p. 32). In this respect, teachers and practitioners are highly recommended to change their beliefs and attitudes regarding method era and postmethod objectives to obtain a good result in their teaching.

\section{Statement of the problem}

Considering $\mathrm{CP}$ and $\mathrm{PP}$ as the influential approaches in language learning and teaching is not far-fetched. CP en- compasses large areas such as curriculum design, teacher education, learners' empowerment and emancipation, sexism, racism, cross cultural studies, etc. In education, many movements and changes in different jurisdictions are due to CP's tenets, yet under different labels and names. By way of explanation, the aims and objectives of newly developed concepts are in line, implicit and derived from CP but under different headings. This might not be problematic for the science or scientific assumptions but it is highly crucial for the proponents of a field. Many teachers and practitioners might practice postmethod pedagogy but they might not be aware of the oppositional purposes and theoretical background of this model. Furthermore, there are number of criticisms toward PP and CP which might not take into account the intellectual, dynamic and open-mindedness of CP and PP. In other words, some of these criticisms might consider CP and PP from the static point of view and from the lens of banking model of education or method- based perspectives.

\section{Objectives and Significance of the Study}

This study aims at investigating the common ground in critical pedagogy and postmethod pedagogy to indicate intellectualism. The extent of similarity and shared beliefs in these approaches are under the magnifier. To this end, definitions of these approaches are brought into consideration. Later on, the features and jurisdictions are identified along with some criticisms towards CP and PP. In the conclusion, the attention is driven to formidable intellect of $\mathrm{CP}$ and PP by identifying the roots of some of the criticisms. By understanding the elaborated and analyzed underlying assumptions of $\mathrm{CP}$ and PP, it is hoped to enlighten teachers, syllabus designers, test designers and practitioners of $\mathrm{CP}$ and PP to realize the connection between these two approaches. Furthermore, the revisited underlying elements of $\mathrm{CP}$ and PP might engrosses teacher/researcher to expand their involvement in the field of research for more democratic teaching and learning circumstances.

For the sake of elaboration on this matter, understanding the theoretical precepts might alter or enhance teacher beliefs. Xu (2012) mentioned categorized teachers' beliefs toward three main classifications about learners, learning and teachers themselves. Based on Meighan (1990) the beliefs of teachers toward learners entrenched seven main classifications, namely, resistors, receptacles, raw materials, clients, partners, individual explorers and democratic explorers (cited in Williams and Burden, 1997). Regarding the teachers' attitude toward learning, Williams and Burden's (1997) classification encompassed two broad reproductive and meaning-based approaches. Last but not least, an important notion regarding the teachers' beliefs about themselves which are both inline with the principles of postmethod and critical pedagogy is discussed. Permissiveness or permission to be oneself was an important notion that remarkably valorizes freedom to have ideas, beliefs and values. Despite the fact that $\mathrm{Xu}$ (2012) classification was duplicated of the Williams and Burden's (1997) identification, all of the mentioned criteria came from teacher's beliefs and these beliefs affect the classroom procedure directly. 
According to Florance (2011), teacher education might not change teachers' beliefs in different vantage points. To this end, the challenge between global and local knowledge is one of the enumerated objectives of postmethod pedagogy. However, there might be a discrepancy between claims of postmethod teachers who were still majorly relying on method after their graduation from teacher training courses. One reason might be the limited discussion of oppositional movement of postmethod pedagogy against the western or global knowledge. Another reason might be due to the beliefs, attitudes, aims and objectives. All in all, this paper aims at revisiting the constructive elements of critical pedagogy in post method pedagogy for the sake of better understanding and enhancement.

\section{CRITICAL PEDAGOGY AND POSTMETHOD PEDAGOGY}

It is intended to shed light on the aims and objectives of $\mathrm{CP}$ and PP by reviewing and juxtaposing important elements such as teachers and learners' role along with the features of these approaches. In essence, some theoretical assumptions, empirical studies and some criticisms are discussed briefly to indicate the different angles of these approaches.

\section{Banking Model, Problem-posing Model and Postmethod Pedagogy}

The perspectives of Paulo Freire toward education and teacher-learner relationship are unique and worthy of consideration. The first notion to be highlighted is the concept of narration. In many educational systems, even in this era teachers play the role of subject narrator and students are marginalized listening object. This notion goes back to the hay days of structuralism and behaviorism which upholds language-centered pedagogy. Also, the fainted marginalized characteristics of the teachers and learners' relations move toward learning-centered pedagogy as well. Accordingly, Paulo Freire (1970) mentioned that "education is suffering from narration sickness" (p. 71). Positivism and its psychometric attribution enhanced this shortcoming. Teachers and learners relations were dictated in callous, soulless, and static way. These are also self-evident in quantitative research method (Dorney, 2007). Even in today education in many situations the inherent characteristics of researchers adhere to quantitative view of education and go back in cyclic motion to the idea of narration sickness developed by Paulo Freire. In this approach, the teachers' role was to narrate learners. This is when the importance of memorization came into account. Teachers filled students with knowledge (the source of knowledge, its definition, where it comes, who confirmed it was not important) and learners had to delve the subject matter to memorize it. Therefore, more closely a learner imitated the lecture and the dictated knowledge of a teacher, more prosper that learner would be in this approach. This perception is in line with the theories such as jug and mug or clay and molding (Williams \& Burden, 1997).

Teacher's characteristics of this model were to be the source of authority, source of knowledge, controller, choos- er, and speaker; on the other hand, learners were accepters, empty vessel of knowledge, recipients, object, controlled and disciplined (Freire, 1970). In this model teachers were at the center of attention not at the center of educational change as mentioned by Kumaravadivelu (2006). Accordingly, one might consider the word teacher as a source of power to control testing system, syllabus, and curriculum. But in reality this might not be the case. Teachers were similar to the leaners in this model. A good teacher was the one who taught what he/she had to teach. In accordance, teachers of this model were mere representatives of what curriculum asked them to do. Akbari (2007) stated "education is too important to be left to the classroom teacher, the school board, the central ministry or any other single person or group" (p. 192). This claim highlights the importance of dynamicity, norms and values in education.

The aforementioned points were the characteristics of banking model. This model tries to develop the adapted educators in which passivism imposed to them leave little room for critical consciousness or critical awareness. Kumaravadivelu (2006) discussed this concept at the global level and stated that "the process of marginalization cannot survive without the practice of self-marginalization" (p. 219). The process of marginalization in the case of CP and at local level can be viewed in terms of teacher and leaners. Easy acceptance of western theories by teachers is one concept in the process of marginalization and easy acceptance of leaners over the materials introduced by their teachers accelerates this notion. Generally, teachers rely mainly on commercial textbooks, westernized education and particular framework developed at institute or educational levels in many circumstances. Similarly, learners have no other choices than naïve acceptance of teachers as a reliable source in their settings. In this case, both teachers and learners were marginalized. Teachers are marginalized by western's theories and learners are marginalized by their teachers.

Another debilitative feature of banking model is the rejection of the partnership. The partnership comes from mutual role and mutual experience. We can see the discrepancy in many educational systems and programs in terms of the partnership and the mutual role of teachers and learners. However, these programs unlike their claims see learners as passive, empty containers who should receive prescribed knowledge. In this regard, Freire (1970) remarked that "verbalistic lessons, reading requirements, the methods for evaluating knowledge, the distance between the teacher and the taught, the criteria for promotion: everything in this readyto-wear approach serves to obviate thinking" (p. 76). In this statement, it is crystal clear that ready made approaches to education serves banking model and denies partnership. For instance, the methods for evaluating prescribed knowledge are directly related to the analysis of knowledge in realization of true from false (Kincheloe, 2008). This knowledge is rather radical by means of using predefined sets of rules, strategies and contexts which will create dominant epistemology or what Freire calls ready-to wear approach. This view of knowledge within different epoch might differ but the domination of specific school of thought would stay con- 
stant. Monchinski (2008) rephrased the notion of dominant knowledge as "positivism is an epistemology, a knowledge theory, holding that true knowledge, things we can really know (positively know), is scientific knowledge, based on natural phenomena, their properties, and relations, and is empirically verifiable" (p. 50). Banks (2005) directly criticized the legitimized power and unveiled the fountain of this social inequality as construction of knowledge that marginalized people. Thus, this rational has been derived from the source of power and mainly leans toward the banking model which transmission of knowledge is centralized.

To indicate the milestone in liberal education, Freire (1970) divulged that we neither have the true knowledge which could be transferred, nor have the true culture to be adapted. Freire introduced the problem-posing model. This model is also referred to as liberating education that considers men and women as consciousness and active participants. This model emphasizes on the partnership of teachers and learners and acts on cognition and transformation instead of transmission of knowledge. Accordingly, Auerbach (1992) classified the problem-posing stages into the listening phase, the dialogue phase, the decoding and recoding phase along with the action phase. These stages elaborated on actual classroom performance. It is worthwhile to mention that in the final stage learners achieve sense of reflection in the real world phenomena. In this classified model, teacher was not merely the source of knowledge to fill the empty pots. Teachers of this model were not the source of power; instead maintained dialogic interactions through democratic settings. Postmethod teachers share the same intentions and characteristics with CP practitioners. Two underpinned features of postmethod teachers are autonomy and reflection; in which, Tasnimi (2014) highlighted the action research as an important point in reflection. In banking model knowledge is fixed and dictated to the teachers by method packages with little or no room for reflection (Kumaravadivelu, 2006). As a result, teachers are not autonomous in this case and it "is closely linked to particular school of thought" (Kumaravadivelu, 2006, p. 179). Different schools of thought develop different beliefs and ideas which restricts autonomy. To emancipate this restriction a solution was mentioned by Bakhtin (1981); namely, dialogic interaction which was based on the freedom of expressing one's belief, idea and identities in education to achieve autonomy.

The second feature of postmethod was reflection which has a valuable role in education. Freire continuously emphasized on the reflection in problem-posing model. In a similar vein, John Dewey (1916) emphasized on the reflection in education which the similarities between Freire's perceptions toward education and Dewey's reflective thinking were highlighted by Larsen-Freeman (2011). Unfortunately, the notion of reflection is so vast and dynamic which unified definition is far-fetched. Also, Loughran (2002) pinned the problem on the meaning of reflection. Both teachers and learners can be reflective. To this end, Kumaravadivelu (2006) stated that postmethod pedagogy enhanced the capacity of teachers to reflect to their teaching. Considering leaners, Freire (1970) emphasized on the reflection of educators according to their own definition of realty which further action should come into account. Furthermore, Akbari (2007) put reflective action against impulsive and routine action. Among these classifications proponents of reflective action uphold critical examinations. In the process of teaching one can not simply rely on experience to attain the best results for leaners, but other elements such as critical reflation plays important role (Loughran, 2002).

In a reflective view, Fendler (2003) made common case with $\mathrm{CP}$ in terms of feminism. Feminism and sexism in many circumstances were used interchangeably; where as, feminism is one of the branches of sexism. Therefore, reflection could be considered as a crucial aspect in educational systems which embarked ideologies such as racism and sexism. Hooks $(1988,2000)$ tried to expand the concept of "sisterhood is universal" to solve the problem of racism (priority of white female feminist as pioneers) in the sexist education. She expressed that "as long as women are using class or race power to dominate other women; feminists sisterhood cannot be fully realized" (Hooks, 2000, p. 16). This view is a transparent example of reflection.

Since the nature of the problem in CP can be faced both at macro and micro levels, both classifications as stated by Akbari (2007) namely reflection-on-action ${ }^{1}$ and reflection-in-action ${ }^{2}$ should be taken into consideration. Learners of problem-posing and postmethod pedagogy are active participants who critically scrutinize the knowledge through dialogic interaction with teachers. By posing the problem, learners try to actively participate to compensate the issues according to their own definition of reality. In this model "women and men, simultaneously reflecting on themselves and on the world" that results in awareness, consciousness, perception and contemplation (Freire, 1970, p. 82). Similarly, Kumaravadivelu (2006) described postmethod learners as pedagogic decision makers. In this case, learners are actively participating in their educational lifespan which results in autonomous learners. Although the terminology of $\mathrm{CP}$ and PP might differ in identifying leaners, but the interpretation and constructing elements are identical. Both models clearly declared autonomy and active participation as their main goals. In this respect, Kumaravadivelu (2006) stated two views in relation to learner's autonomy, namely, narrow and broad view. In narrow view the attention is toward developing leaners with learning to learn characteristics; however, broad view aims at learning to liberate, autonomy and empowerment in critical thinking. The intention of broad view, liberation, is transparent and in line with the aims and objectives of problem-posing model. Critical thinking which might result in decision making and autonomy was characterized by Pennycook (2001) in narrow sense as "a way of bringing more rigorous analysis to problem solving or textual understanding, away of developing more critical distance as it is sometimes called" (p. 4). Furthermore, Pennycook (2001) added the concepts of power and disparity to this statement in order to achieve more comprehensible definition for critical applied linguistic. The concept of power in education was a long-lasting argument.

The reflection to standard knowledge which was discussed in preceding paragraphs has been an important factor. In teacher education, Day (2006) categorized knowledge into 
content, pedagogic, pedagogic content and support knowledge. To become more efficient, teachers can reflect on these categories in teacher education programs. One of the possible sources for developing banking model and serving dictated methods is teacher education programs which in many countries has watertight characteristic. Kumaravadivelu (2006) pointed out two models of teacher education, namely, transmission and transformative. Transmission model is similar to the apprentice-expert model mentioned by Day (2006) and has some characteristics of banking model and method-based model of education. In contrast, transformative model is the one that $\mathrm{CP}$ and postmethod pedagogy seek. In this model neither knowledge nor pedagogical theories is dictated. Teachers use their own theory and definition of teaching in their classes. This model is in line with the integrative model mentioned by Day (2006). All in all both CP and PP aim at bringing justice and liberty in education. To have a better perception, it is of value to study some criticisms of CP and PP.

\section{Some Criticisms on CP and PP}

Although the merit and the importance of $\mathrm{CP}$ are highly magnificent, but there are some criticisms towards Freire's theoretical perceptions and CP. Jay and Graff (1995) argued that Freire predefined the identity of oppressor and oppressed whereas there were different definitions for both terms (cited in Freire, 1970). Delpit (1988) made a remark about the absence of attention toward academic skills in CP; on the other hand, Ravitch (2000) criticized CP for being idealistic and theory-centered (cited in Duncan-Andrade \& Morrell, 2008). Popkewitz and Brennan (1998) also pointed out that CP mainly investigated analysis and questions with regard to the social circumstances which resulted in formulaic identified conventions. Breuing (2011), in a qualitative study, investigated the definitions, aims and influential theories of $\mathrm{CP}$ among seventeen critical pedagogues including 10 female and 7 male in the 50 to 60 years old age group. The result of Breuing's study (2011) indicated that there was more than one true definition for $\mathrm{CP}$ and critical pedagogues should explain in detail the idea of social justice which had been represented by the majority of participants; furthermore, the important theorists of $\mathrm{CP}$ were less frequently referred to by the participants.

The importance of a theory and deviation from its strands in practice could be considered a fracture; in which, the utopia of theorists and their theoretical assumptions were not always apparent in practice. Kumaravadivelu (1994) tried to compensate the absence of practicality of theories in the classrooms by developing macrostrategic framework. This framework was influenced by the three-dimensional framework of Stern and the exploratory practice framework of Allwright. In a nutshell, macrostrategic framework was a broad concept in relation to L2 learning and teacher education which upheld method-neutral conditions (Kumaravadivelu, 2006). On the contrary, Bell (2003) criticized postmethod through examining its roots in postmodernism and stated that:

postmethod rather than being evidence of the maturation of teaching practices, is further manifestation of the search for method and so is subject to the same criticism. Postmethod, despite its disparagement of innovations called methods, can be seen as an attempt to unify these disparate elements into a more holistic, redefined communicative language teaching (CLT) through a dialectical process of building and deconstructing forces (p. 326).

Parallel with this criticism, Akbari (2008) criticized PP for being philosophical in that Kumaravadivelu "stops short of offering any viable solutions, systematic solution as to how these barriers can be overcome and what mechanisms must be put in place to create the desirable context for teacher autonomy and growth based on a postmethod pedagogy" (p. 645). Moreover, Akbari (2008) problematized PP for neglecting realities such as framework developed by ministry of education in different countries, harmless topics of commercial textbooks, economical and time constraints of teachers, etc. Therefore, based on these assumptions, the principles of PP might be beyond the classroom practices. Also, Razmjoo, Ranjbar, and Hoomanfard (2013) highlighted that the implementation of postmethod principles was far-fetched especially regarding the parameters of practicality and possibility in Iranian context. Additionally, Naseri Kimavand, Hessamy and Hemmati (2016) found learners' lack of interests in relation to the strategic learning, time limitation and prepackaged syllabi available in Iranian market as the major challenging factors of postmethod pedagogy. Ahmadian and Erfan Rad (2014) remarked that postmethod pedagogy was highly teacher-dependent and a critical teacher education program was needed for developing PP.

\section{CONCLUSION}

In this article, the major definitions and intentions of $\mathrm{CP}$ and PP were discussed. These definitions and intentions were to certain extant similar to each other. Kumaravadivelu (2006) directly mentioned that parameters of possibility owed its origin to Freire and CP to indicate the oppositional purposes. In fact, these elaborations were to highlight the dynamic, open-minded, intellectual, problem solving, critical thinking and unbiased nature of PP. With regard to the educational philosophies, Ornstein (2011) identified similar roles such as democratic education and problem solving features for progressivism. Accordingly, Urban (2013) brought the criticism of Hofstadter (1963); namely, anti-intellectualism of progressivism and criticized Dewey for the neglect of the importance of the subject matter. This criticism shows the standpoint of Hofstadter, but Urban (2013) mentioned that "it surly was not Dewey's goal to abandon intellectual purpose" (p. 19). Concomitantly, Dewey, Freire, and Kumaravadivelu viewed education dynamically and intellectually. But some of these criticisms seemed static and anti-intellectual in their nature. Moreover, these constraints and problems may be due to the nature of the banking model and method-based approaches which considers teacher as an automaton in tightly controlled settings. Since, identification of the stances of the critiques is beyond the scope of this paper, some criticisms toward PP are discussed briefly.

For instance, Akbari (2008) criticized Kumaravadivelu for the absence of offering viable solutions and mechanisms 
to compensate the barriers. To highlight the intellectual aspect of PP, it is possible to bold that unified frameworks and pre-defined solutions of the global theorists to barriers for local settings might impede and faint the premises of $\mathrm{CP}$ and PP. In other words, developing a fixed framework and guide line that Akbari (2008) sought not only could tackle the intellectual priorities of these approaches but also might categorize PP in the method classification, in which instead of western theorist Kumaravadivelu theorized and teachers/ practitioners had to consume. Furthermore, PP was also criticized for constraints such as ministry of education, time and income. In this respect, dynamicity of PP model may be a good respond to these criticisms. Since, Kumaravadivelu (2006) did not dictate an A to Z model which practitioners should follow every single layer to gain a good result of their teaching, proponents of this approach may use applicable strategies to their settings. For the income and limited available time, teachers and practitioners should find a way to work within these constraints and make the best possible result out of their classrooms. For instance, Nation and Macalister (2010) stated that "it is usually necessary to examine the nature of the constraint in the environment you are working in and to examine previous research on the constraint" (p. 18). This investigation may identify possible sources of constraints and possible solutions for empowerment and emancipation of PP and CP's practitioners by themselves.

Generally, the criticisms toward both approaches were to some degree parallel especially regarding the philosophical issues. However, PP is more pertinent to the classroom procedure comparing to $\mathrm{CP}$ which is at the theoretical level. To some extent, both models were similar in terms of characterizing teachers, learners and contexts. To a certain extent, the CP and PP's approaches to teaching were on common ground. They were both served the intention of emancipation and empowerment.

Some dynamic views on criticisms were highlighted to show the intellectual aspects of these approaches. It is of value to mention that philosophical stages in CP and PP may open a window to more democratic settings in language teaching; in which, local theorists, scholars and practitioners dialogically interact with the local learners.

\section{END NOTES}

1. It is online reflection that can be done by individual

2. It is post hoc reflection that can be done in group

\section{REFERENCES}

Ahmadian, M., \& Erfan Rad, S. (2014). Postmethod era and glocalized langauge curriculum: A fresh burden on language teachers. Journal of Language Teaching and Research, 5(3), 592-598.

Akbari, R. (2007). Reflections on reflections: A critical appraisal of reflective practices in L2 teacher education. System, 35, 192-207.

Akbari, R. (2008). Postmethod discourse and practice. TESOL Quarterly, 42(4), 641-652.
Auerbach, E. (1990). Making meaning, making change: A guide to participatory curriculum development for adult ESL and family literacy. Boston: University of Massachusetts.

Barjesteh, H., Alipour, B., Vaseghi, R. (2013). Critical pedaogy: Imporving Iranian EFL Learner's reading comprehension ability through CP strategies. Indian Journal of Fundamental and Applied Life Sciences, 3(3), 335-341.

Bakhtin, M. M. (1981). The dialogic imagination. Austin: University of Texas Press.

Bell, D. M. (2003). Method and Postmethod. TESOL Quarterly, 37(2), 325-336.

Breuing, M. (2011). Problematizing critical pedagogy. International Journal of Critical Pedagogy, 3(3), 2-23.

Brown, H. (2002). English language teaching in the "post-method" era: Toward better diagnosis, treatment, and assessment. In J. C. Richards, \& W. Renandya (Eds.), Methodology in language teaching: An anthology of current practice (pp. 9-18). Cambridge: Cambridge University Press.

Chege, M. (2009). Literacy and hegemony: Critical pedagogy vis-a-vis contending paradigms. International Journal of Teaching and Learning in Higher Education, 21(2), 228-238.

Day, R. (2006). Models and the knowledge base of second language teacher education. University of Hawaii Working Papers in ESL, 11(2), 1-13.

Delpit, L. D. (1988). The silenced dialogue: Power and pedagogy in educating other people's children. Harward Educational Review, 58(3), 281-298.

Dewey, J. (1916). Democracy and Education. New York: Macmillan.

Dornyei, Z. (2007). Research methods in applied linguistics. Oxford: Oxford University Press.

Duncan-Andrade, J. M. R., \& Morrell, E. (2008). The art of critical pedagogy: Possibilities for moving from theory to practice in urban schools. New York: Peter Lang Publishing.

Fendler, L. (2003). Teacher reflection in a hall of mirrors: Historical influences and political reverberations. Educational Research, 32, 16-25.

Florence, N. (2011). Immigrants teachers, American students: Cultural differences, cultural disconnections. New York: Macmillan.

Freire, P. (1970). Pedogogy of the oppressed. New York: Continuum Books.

Hashemi, S. M. (2011). (Post)-methodism: Possibility of the imposible? Journal of Language Teaching and Research, 2(1), 137-145.

Hooks, B. (1988). Talking back: Thinking feminist. Toronto: Between the Lines.

Hooks, B. (2000). Feminism is for everybody: Passionate politics. Cambridge: South End Press.

Huda, M. E. (2013). Post-method pedagogy and ELT in Bangladesh. Global Journal of Human Social Science Linguistics \& Education, 13(7), 7-14.

Kincheloe, J. L. (2008). Knowledge and Critical Pedagogy. Montreal: Springer Science. 
Kumaravadivelu, B. (1994). The postmethod condition: Emerging strategies for second/foreign language teaching. TESOL Quarterly, 28(1), 27-48.

Kumaravadivelu, B. (2006). Understanding language teaching: From method to postmethod. New Jersey: Lawrence Erlbaum Associates.

Larsen-Freeman, D. (2000). Techniques and principles inlanguage teacheing. Oxford: Oxford University Press.

Larsen-Freeman, D. (2011). Key concepts in language learning and language education. In J. Simpson (Ed.),

Routledge handbook of applied linguistics (pp. 155-170). London: Palgrave Macmillan.

Leonardo, Z. (2002). The souls of white folk: Critical pedagogy, whitness studies, and globalization discourse. Race Ethnicity and Education, 5(1), 29-50.

Loughran, J. J. (2002). Effective reflective practice in search of meaning in learning about teaching. Journal of Teacher Education, 53(1), 33-43.

Monchinski, T. (2008). Critical Pedagogy and the Everyday Classroom. New York: Springer.

Naseri Kimavand, P., Hessamy, G. R., \& Hemmati, F. (2016). Postmethod education: Its applicability and challenges in Iran. International Journal of Asian Social Science, 6(1), 21-34.

Nation, I. S. P. \& Macalister, J. (2010). Language curriculum design. New York: Routledge.

Ornstein, A. C. (2011). Philosophy as a basis for curriculum decisions. In A. C. Ornstein, E. F. Pajak, \& S. B. Ornstein (Eds.), Contemporary issues in curriculum ( $\left.5^{\text {th }} \mathrm{ed}.\right)$. Upper Saddle River, NJ: Pearson Education, Inc.

Pennycook, A. (2001). Critical applied linguistics: A critical introduction. Mahwah: Lawrence Erlbaum Associates, Inc.
Popkewitz, T., \& Brennan, M. (1998). Restructuring of social and political theory in education: Foucault and a social epistemology of school practices. Educational Theory, 47(3), 3-38.

Razmjoo, S. A., Ranjbar, H. \& Hoomanfard, H. M. (2013). On the familiarity of the Iranian EFL teachers and learners with postmethod and its realiziation. International Journal of Language Learning and Applied Linguistics World, 4(1), 1-12.

Richards, J. C. (1990). "Byound methods.” In J. C. Richards, The language teaching matri: Curriculum, methodology, and materials (pp.35-45). Cambridge: Cambridge University Press.

Rivers, W. M. (1968). Teaching Forign-Language Skills ( $2^{\text {nd }}$ ed.). Chicago: The University of Chicago.

Shor, I. (1992). Empowering education: critical teaching for social change ( $1^{\text {st }}$ ed.). Chicago: University of Chicago Press.

Stern, H. H. (1983). Fundamental concepts of language teaching. Oxford: Oxford University Press.

Tasnimi, M. (2014). The role of teacher in postmethod era. Express, an International Journal of Multi Disciplinary Research, 1(3), 1-8.

Urban, W. J. (2013). Anti-progressivism in education: Past and present. International Journal of Progressive Education, 9(1), 14-24.

Watson, G., \& Glaser, E. (2002). Critical thinking appraisal. London: The Psychological Corporation.

Widdoson, H. G. (1990). Aspects of language teaching. Oxford: Oxford University Press.

$\mathrm{Xu}, \mathrm{L}$. (2012). The role of teachers beliefs in the language teaching- learning process. Theory and Practice in Language Studies, 2(7), 1397-1402. 